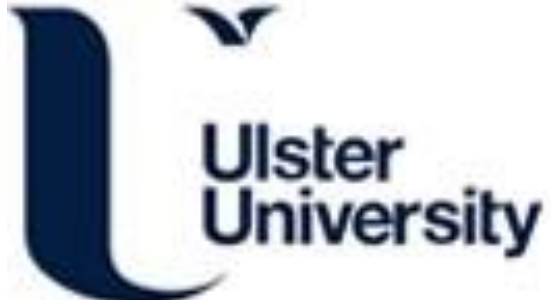

\section{Explaining policy deadlock: the case of Sarkozy's integration policy}

Mckeever, A. (2020). Explaining policy deadlock: the case of Sarkozy's integration policy. French Politics, 19, 51-64. https://doi.org/10.1057/s41253-020-00105-x

Link to publication record in Ulster University Research Portal

\section{Published in:}

French Politics

Publication Status:

Published (in print/issue): 27/01/2020

DOI:

10.1057/s41253-020-00105-x

\section{Document Version}

Author Accepted version

\section{General rights}

Copyright for the publications made accessible via Ulster University's Research Portal is retained by the author(s) and / or other copyright owners and it is a condition of accessing these publications that users recognise and abide by the legal requirements associated with these rights.

\section{Take down policy}

The Research Portal is Ulster University's institutional repository that provides access to Ulster's research outputs. Every effort has been made to ensure that content in the Research Portal does not infringe any person's rights, or applicable UK laws. If you discover content in the Research Portal that you believe breaches copyright or violates any law, please contact pure-support@ulster.ac.uk. 


\section{Explaining policy deadlock: the case of Sarkozy's integration policy}

What processes account for the deadlock in a given policy? While causes and mechanisms of policy change have been extensively researched, this paper sheds light on how formal institutional change can lead to policy deadlock. This paper examines two cases that demonstrate the absence of progress on integration policy during Sarkozy's time in office (as a minister of the Interior and as a president). Drawing on elite interviews, the paper points out to how institutional change can lead to departmental competition within new or combined structures, leading to deadlock, as new layered actors do not always have the capacity to push old ones out, resulting in further institutional change.

Keywords: policy deadlock, causal mechanisms; integration policy; Nicolas Sarkozy ${ }^{1}$.

\section{Introduction}

Integration has developed into a prominent issue in France in 1980s following the long-term settlement of millions of immigrants, who arrived from its former colonies - Algeria, Morocco and Tunisia, but also from other countries of North Africa (Adida et al. 2014; Hollifield 2014). The question of integration has been quickly picked up by the radical right Front National. Following its first electoral success in 1983, the integration issue became incorporated in the agenda of both left- and rightwing parties (Guiraudon 2005: 156) and since then remained of crucial importance in France.

Using the case of Sarkozy's integration policy, I argue that institutional change led to departmental competition within newly created or merged structures, resulting in policy deadlock and further institutional change. More specifically, 'institutional

\footnotetext{
${ }^{1}$ Dr Anna McKeever, Ulster University, School of Applied Social and Policy Sciences, Newtonaabbey, Shore road, BT370QB, office 14L02. Phone: +447462807251.
} 
layering - the introduction of new rules alongside the existing ones' (Mahoney and Thelen 2010: 15) generates departmental competition within new or merged institutions. Departmental competition acts as a constraint to the development and implementation of policy, encouraging opposition between senior civil servants, ministers and their staff, who refuse to cooperate, leading to policy deadlock. Policy deadlock is an inability of the institution and the staff in charge of policy-making to agree on the development of a specific policy. This, in turn, prevents policy change and leads to further institutional change.

Integration policy was a cornerstone of Sarkozy's political agenda during his time in the office, both as a minister of the Interior and as a president of France underwent some changes. When Sarkozy was appointed the minister of the Interior in Chirac's government in 2002, he argued for positive discrimination of immigrants and French of immigrant origin. Following 2005 riots in French suburbs, Sarkozy’s integration policy paradigm changed from anti-discrimination to equal opportunities approach. The adoption of equal opportunities paradigm resulted in the creation of the new institution in charge of equal opportunities - ACSE (Agence Nationale pour la Cohesion Sociale et l'Egalité des Chances), which was placed under the authority of the Ministry of Urban Policy (Ministère de la Ville), leading to the first integration policy deadlock. The essence of this deadlock was that integration policy became dominated by the urban policy, which eventually resulted in the re-separation of these policies and transfer of integration policy to the Ministry of the Interior. A second integration policy deadlock occurred when the Ministry of Immigration, Integration, National Identity and Co-Development that was designed to improve integration and created shortly after Sarkozy's election as a president, was abolished three years later. Sarkozy's integration policy has been previously explained through a prism of causal factors, which included 
mobilisation of particular sections of the electorate, intra-party competition and partisan veto players (Carvalho 2016; Carvalho and Geddes 2012). This article focuses on explaining these integration policy deadlocks by elucidating the mechanisms that accounted for it.

The article proceeds as follows. The first part demonstrates how institutional change and departmental competition, which is a product of this change can be used to explain policy deadlocks. The second section proceeds with unpacking departmental competition, which explains integration policy deadlock which occurred as a result of the shift from anti-discrimination to equal opportunities paradigm during Sarkozy's time as the minister of the Interior. The article then examines how 'institutional layering' (Streeck and Thelen 2005; Mahoney and Thelen 2010) led to departmental tensions, which resulted in the abolishment of the Ministry of Immigration, Integration, National Identity and Co-Development, which aimed to improve integration.

Conclusion explains how institutional change can lead to tensions among ministers and their staff, and senior civil servants in these new or combined institutions, which results in policy deadlock and further institutional change.

\section{Methods}

This paper relies on process tracing as a method of within case analysis (Beach and Pedersen 2013; Beach and Pedersen 2016; Bennett and Checkel 2015; Blatter and Blume 2008; Bennett 2010). It views causal mechanisms as probabilistic, meaning that their operation cannot be pre-determined but is intimately context-dependent (Beach and Pedersen 2013; Faletti and Lynch 2009). A probabilistic understanding of mechanisms helps to make stronger causal inferences than a deterministic one, by stressing the importance of appropriate contextualisation of mechanisms to avoid 
flawed causal inferences (Bengtsson and Herrting 2014; Faletti and Lynch 2009;) and generalises causal mechanisms based on the context in which they operate.

The explanation of integration policy deadlock during Sarkozy's time in office relies on twelve semi-structured interviews, including Sarkozy's former adviser, the current French prime minister, French senior civil servants from the Ministry of the Interior and later the Ministry of Immigration, Integration, National Identity and CoDevelopment and senior Union for a Popular Movement (UMP) MP politicians ${ }^{2}$.

The first-hand accounts explaining integration policy deadlocks were collected over the course of several trips to Paris in 2016. As an outsider to France, and the French political class, it was difficult to obtain responses from potential interviewees. At the initial stage I contacted potential interviewees via email and phone. In order to increase the number of interviewees, I employed snowballing technique, which proved to be successful. All interviews were conducted face-to-face.

Elite interviews are the best option to document and explain integration policy making as they allow researchers 'to obtain accounts from the direct witnesses to the events in question' (Tansey, 2007: 767). Furthermore, they 'offer political scientists a rich, cost-effective vehicle for generating unique data to investigate the complexities of policy making' (Beamer 2002: 86). While understanding that targeted sampling can cause selection bias (King et al. 1994), it is the best strategy to explain the policy gaps as 'certain categories of individuals may have unique, different or important perspective

\footnotetext{
${ }^{2}$ While some interviewees were happy to go on record, others only agreed to speak to me on the basis of their accounts being anonymous. For the sake of brevity, not all the interviews that I conducted are quoted in this paper. The paper only includes the clearest or most compelling examples, however I do give preference to on-the-record testimony, within the themes that appeared in the sample of twelve interviews that I conducted.
} 
and their presence in the sample should be insured' (Robinson 2014: 32). Where possible, I corroborated the evidence from the interviews with primary sources, but most of the observations rely on information provided by the interviewees, which is not in public record.

\section{Explaining policy deadlock: an institutionalist approach}

A number of studies highlight that different sets of actors can influence policymaking process, including interest groups (Hampshire and Bale 2015; Freeman 1995; 2001), ethnic groups (Abadan-Unat 2017) and courts (Guiraudon 1997; Joppke 1998). This paper argues that political elites, ministers, senior civil servants and street-level bureaucrats (Consterdine 2015; Lipsky 1979; Somerville 1997; van der Leun 2003) and institutions that they work within played a key role in creating integration policy deadlock. Taking the change from anti-discrimination to equal opportunities paradigm in 2006 and the creation and abolishment of the Ministry of Immigration, Integration, National Identity and Co-Development as cases, the paper points to institutional layering and departmental competition as mechanisms that explain integration policy deadlock and highlights the crucial role that senior ministerial advisers, ministers and civil servants played in it. It takes an institutionalist perspective, arguing that integration policy deadlock stems from institutional change.

This paper makes a contribution to public policy literature by explaining how formal institutional change can account for policy deadlock, in other words, any progress on a given policy development. As institutions 'both constrain and condition the behaviour of political actors' (Consterdine 2015: 131), institutional change has a direct impact on a policy change or on the absence thereof. Therefore, one needs to look at the institutional change and its different mechanisms to explain why there has not been any progress made on a given policy. Some of such mechanisms include 
'institutional layering', which Mahoney and Thelen (2010: 15) define as 'the introduction of new rules on top of existing ones', which affects the behaviour of the actors in that institution (Thelen 2003). Mahoney and Thelen (2010: 17) argue that layering can lead to substantial policy change. While Streeck and Thelen (2005: 31) posit that institutional layering destabilises institutions, where the old core is usually replaced by the new core, this paper contributes to the literature on institutional change by arguing that it is not necessarily the case and that new layers can be pushed out by the old core, leading to policy deadlock and further institutional change.

As institutions tend to resist the change, both in terms of circumstances and actors' preferences (March and Olsen 1989; 1995), institutional layering can lead to the tensions that arise within the institutions, which have been labeled as 'departmental competition' (Hampshire and Bale 2015) or 'departmentalism' (Kavanaugh and Richards 2001). This mechanism has been used to explain the formation of Labour's liberal immigration policy regime (Consterdine 2015; Consterdine 2018) and the introduction of restrictive immigration policies under the Conservative-Liberal Democrat government (Hampshire and Bale 2015). This paper highlights how formal institutional change can result in departmental competition, which leads to policy deadlock. Departmental tensions can be a result of the political relationships between actors (Suleiman 1976) where different departments want to reassure their centrality in policy-making process (Bezes 2009). The competition is usually structured by power relations within institution, where different departments have unequal policy influence because of the lack of financial resources or the lack of information to assert influence (Suleiman 1974). The competition is also aggravated by the autonomy that civil servants working in these departments acquire (Geniyes 2005), which stems from the 
education practices in the Grandes Ecoles they graduate from (Birnbaum 1982; Bourdieu, 1996).

Integration policy deadlock can be explained by focusing on the role of ministers and their administrations in policy-making process. When institutional change happens, it triggers departmental competition within new structure. The tensions within new institutions responsible for a given policy-making are structured not only by different weight that departments have within an institution, but also by considerable autonomy that civil servants and ministers acquire during their careers.

\section{From anti-discrimination to equal opportunities paradigm}

Shortly after his appointment as Minister of the Interior in Chirac's government in 2002, Sarkozy promised to improve integration by taking a positive discrimination approach towards foreigners and French of immigrant origin (issus de l'immigration). As minister of the Interior, Sarkozy stressed the importance of making integration more efficient by focusing on the integration of those people, who were discriminated in the communities, which by and large are populated with immigrants and the French of immigrant origin (Simon 2009). This positive discrimination approach was bold and distinguished Sarkozy from president Chirac's position, putting him at odds with the the French republican tradition, where individuals are defined without considering their gender, social and ethnic background and place of residence (Drake 2011; Marthaler 2008; Simon 2007).

Sarkozy's integration approach was centered around cultural integration, supporting the ban of religious symbols in state schools (Loi encadrant, en application du principe de laïcité, le port de signes ou de tenues manifestant une appartenance religieuse dans les écoles, collèges et lycées publics), but neglected socio-economic integration in socially deprived areas with high immigrant concentration. It had not 
focused on addressing economic integration, which meant incorporating people into French society by erasing discrimination against immigrants and the French of immigrant origin, creating opportunities for achieving better educational results, decreasing unemployment and increasing wages. As a number of interviewees pointed out, addressing integration only from cultural perspective, which has been notably advocated by FN, was Sarkozy's attempt to neutralise the competitor, which, similarly to Sarkozy, did not care about improving the economic position of immigrants and providing better chances for them (Interview with the current French prime minister Edouard Phillipe 2016; Interview with the UMP MP 2016). It was more acceptable to show the electorate that on cultural integration Sarkozy toughened the rules, it was more politically risky to address economic integration (Interview with Sarkozy's former adviser 2016). An absence of political will explains the lack of socio-economic integration, as Sarkozy feared that increasing economic investment into integration would not find widespread public support (Interview with Marie-José Bernardot, former head of the Office for territorial, social and cultural integration in the Ministry of the Interior 2016).

As 2005 riots highlighted socio-economic deprivation in Parisian suburbs and in French suburbs more generally, Sarkozy was forced to address socio-economic integration. The riots erupted in Parisian suburbs, showing a public backlash against the electrocution of two teenagers of immigrant origin who were followed by the French police (Mucchielli and Goaizou 2007). They signalled the marginalisation of French citizens of immigrant origins by the French authorities, not the positive discrimination that Sarkozy promised in 2002 (Marthaler 2008). The riots led to the evolution of integration policy, by triggering an important change in Sarkozy's integration approach, shifting it from an anti-discrimination to an equal opportunities paradigm. Sarkozy 
decided to replace the institution responsible for discrimination against immigrants and French issus de l'immigration FASILD (Fonds d'action et de soutien pour l'intégration et la lutte contre les discriminations) with ACSE. The anti-discrimination paradigm had been implemented by the FASILD, a governmental agency that had been in charge of integration of immigrants or those of immigrant origin, living primarily in disadvantaged areas (quartiers prioritaires) as well as the fight against their discrimination (Senat n. d.).

Name change also reflected change in mission. While FASILD targeted discrimination of the immigrants and French of immigrant origin, ACSE was no longer working with the immigrant population and instead focused on reducing territorial inequalities (Escafré-Dublet 2014: 5). Policy of equality of opportunity applied to all French citizens irrespective of their origin, but by and large, ACSE's policies 'while not targeted - disproportionally affected people of immigrant descent (Escafré-Dublet 2014: 5). But as ACSE's role did not envisage the notion of fighting against discrimination thus hindering socio-economic integration of immigrants and French of immigrant origin (Lepinard and Simon 2008; Noël 2008). This was not in line with the positive discrimination approach promised by Sarkozy because the new institution - ACSE was designed to promote equal opportunities to those living in socially deprived areas (quartiers prioritaires), but not fight against discrimination of these people, as was previously done by FASILD. This represented the change from the promise of positive integration of immigrants and French of immigrant origin to the adoption of the new paradigm, which promoted equal opportunities for every French citizen, not just immigrants or those issus de l'immigration. This change in integration approach erased an important legal instrument of punishment of those who were discriminating, not helping to ensure the equality of opportunities: 
Nicolas Sarkozy closes the only public institution in charge of discrimination FASILD and proposes to create the ACSE that will focus on the notion of equal opportunities $[\ldots]$ which is not attached to legal framework, meaning that in case of discrimination you cannot sentence anyone. (Interview with a former regional director of FASILD and ACSE, Frédéric Callens 2016).

Replacing FASILD, ACSE as a new social actor reunited urban policy (la politique de la ville) and integration policy and was placed under the authority of the Ministry of Urban Policy (Le Ministère de la Ville). I argue that integration policy deadlock occurred because ACSE was layered to the existing institution - the Ministry of Urban Policy, which led to the domination of urban policy over integration, eventually resulting in the re-separation of these policies and transfer of integration into a different institution - Ministry of the Interior. While Streeck and Thelen (2005: 31) argue that institutional layering destabilizes existing institutions, resulting in the defeat of the old layer, the case of urban policy domination within ACSE under the Ministry of Urban Policy demonstrates that the opposite can be true. It shows how a new institutional layer (integration policy) does not necessarily defeat the old one (urban policy), leading to integration policy deadlock. The competition within ACSE between integration and urban policy led to unequal redistribution of financial resources, which were disproportionately allocated in favour of urban policy. As a former head of the Office for territorial, social and cultural integration in the Ministry of the Interior, Marie-José Bernardot explained:

It took time to reform the administration and harmonisation of urban policy with the policy of integration, which originally belonged to two different ministries Ministry of Urban Policy and Ministry of Social Affairs and Integration, which resulted in the domination of urban policy and received the majority of the ACSE's budget (Interview with a former head of the Office for territorial, social and cultural integration in the Ministry of the Interior, Marie-José Bernardot 2016). 
Institutional layering led to the intra-departmental competition within ACSE, where none of the actors were ready to compromise, resulting in the failure of integration policy. A former regional director of FASILD and ACSE, Frédéric Callens underlined:

\begin{abstract}
Departmental competition within the newly formed institution - ACSE resulted in the re-separation of these policies. The wish of every administration to have their own budget and independent decision-making powers, which made cooperation impossible, precipitated the failure of integration policy (Interview with a former regional director of FASILD and ACSE Frédéric Callens, 2016).
\end{abstract}

This competition arises as a result of the political relationships between actors (Suleiman 1976). Different subdivisions within ACSE were driven by different goals, which made cooperation between them problematic. Furthermore, such competition is structured by power relations that exist within a single organisation, where different autonomous subdivisions might have unequal influence (Suleiman 1974: 149). In the case of ACSE, weak subdivisions like integration policy were 'unable to obtain necessary information for asserting the influence $[\ldots]$ and without the necessary means cannot overcome the hostilities' of other subdivisions (Suleiman 1974: 150).

As a result of the inability of integration policy actors to exert influence on the Ministry of the City in terms of decision-making and allocation of resources, integration policy was placed under the responsibility of the Ministry of the Interior, and later under the new Ministry of Immigration, Integration, National Identity and Co-Development. Institutional layering, which attached ACSE to the Ministry of Urban Policy caused departmental tensions between integration and urban policy, leading to the domination of the latter and integration policy deadlock. 


\section{Creation of the Ministry of Immigration, Integration, National Identity and Co-Development}

When Sarkozy announced he would run for the presidency, integration and national identity became one of the major topics of Sarkozy's 2007 presidential campaign with the promise of the creation of the Ministry of Immigration, Integration, National Identity and Co-Development, which would be responsible for tackling the so-called crisis of national identity and improving integration (Ivaldi 2008). Sarkozy pledged that all immigration matters, including integration would be incorporated under the umbrella of one ministry: Ministry of Immigration, Integration, National Identity and CoDevelopment (Sarkozy 2007: 14). By associating immigration with the crisis of national identity, Sarkozy aimed to attract part of the FN's electorate (Carvalho 2017; Mayer 2007). Shortly after becoming the president, the Ministry of Immigration, Integration, National Identity and Co-Development was created, whose role was to 'improve the social integration of immigrants, and to promote national identity' (Duelund 2016: 213). However, linking immigration to national identity provoked strong criticisms among liberals (Ocak 2016) because it 'legitimised perceptions of immigration representing a threat to national identity. The rhetoric around the creation of this ministry was a sign of 'soft nationalism' (Noiriel 2007) and aimed at targeting FN voters during the presidential campaign by stressing the importance of national identity and integration (Marlière 2013: 33).

One of the major events, associated with new Ministry was the debate on national identity, which was launched on Sarkozy's demand by immigration minister Eric Besson in October 2009 (Le Monde 2009). With the pressure not only from the left-wing camp, but also from within his own party, this debate was quickly abandoned in February 2010 when, after three months of discussions on Islam and xenophobia, 
Sarkozy was forced to halt the debate because the public viewed it as unconstructive (Lemarié 2012). Public dissatisfaction with the Ministry of Immigration, Integration, National Identity and Co-Development and with the national identity debate led to the halt of the debate with Sarkozy publicly recognising that it 'had led to tensions and misunderstandings' (Duelund 2016: 213). Aiming to boost his electoral base, Sarkozy has not realised that national identity was not something specific or easy to define, especially in a country like France, which has a long colonial history. As one of the UMP MP's pointed out:

Sarkozy's strategy to start the debate was a political sign for the FN's electorate, made to reassure them that national identity would be taken care of, but the big mistake was that nobody knew what national identity is, it was something that was difficult to describe' (Interview with the UMP MP 2016).

While the halt of the national identity debate is explained by public disapproval, what accounted for the dissolution of the Ministry of Immigration, Integration, National Identity and Co-Development? It was abolished in November 2010 with immigration affairs being placed under the responsibility of the Ministry of the Interior (Wihtol de Wenden 2012: 326). The dissolution of the Ministry, which aimed to improve integration and tackle national identity crisis represented another integration policy deadlock.

Shortly after Sarkozy was elected as president, he created the new Ministry of Immigration, Integration, National Identity and Co-Development in 2007, reuniting the Ministry of Integration and Social Affairs, the Ministry of the Interior and the Ministry of Work under its umbrella. In case of the new Ministry, which united the responsibilities of three different ministries that had their own stabilized rules and conventions, such layering did not result in policy change, but led to opposition of the ministers and their administrations to work together. As Sarkozy's former adviser 
highlighted, there was strong resistance by each of the ministers and their administrations to any compromise on integration, including sharing a common budget and decision-making powers (Interview with Sarkozy's former adviser, 2016). Institutional layering led to departmental competition, which referred to the competition among staff from three different ministries: the Ministry of Integration and Social Affairs, the Ministry of the Interior and the Ministry of Work. Departmental competition implies that policy change is affected by the policy-making logics of different departments within one institution with the departments to have known to protect their interests rather than contribute to the overall policy as they have developed specific cultures of policy-making within their own departments or ministries. The conflicts among ministers and their administration are a result of the politicisation of the French civil servants that have their own political loyalties (Suleiman 1978). Considerable autonomy that civil servants acquire (Genieys 2005: 416), which is enshrined in the educational practices of the French Grandes Ecoles that they attend (Birnbaum 1982; Bourdieu 1996) explains their resistance to cooperation.

Interministerial tensions, which included the resistance to share decision-making powers and path-dependancy of policy-making practices that three ministries and their administrations had, were highlighted by civil servants working inside the Ministry (Interview with a senior civil servant 2016) and by the former head of Interministerial Committee on Immigration Control Patrick Stefanini:

So, we have made it badly, we have put all together. The administrations that have reunited in this new ministry, did not really work together. In addition, there are physical constraints as well. When the people want to work together, physical constraints do not matter. Physically people are in different ministries, but legally they are under authority of one Ministry of Immigration. And, we have not put different services in the Ministry that we should have put because there was a lot of disagreement between the ministries. The new Ministry was created, but the people 
did not want to work together and in three years the Ministry has been dissolved.

(Interview with a senior civil servant and a former head of Interministerial

Committee on Immigration Control Patrick Stefanini 2016).

The conflicts among different ministries reunited under one institution stem from the fact that each ministry aimed to 'reaffirm its centrality in the governance process' (Bezes 2009; 2016). In the context of new Ministry, the conflict related 'to the chains of hierarchical authority that govern relations between multiple levels of organization (distribution of tasks, circulation of information and modes of control' (Bezes 2007: 21). Institutional layering, which fused immigration and integration matters under the authority of three ministries into one, led to departmental tensions within the new institution, which accounted for integration policy deadlock. As a result, the Ministry was eventually dissolved in 2010.

Furthermore, departmental tensions also arose between ACSE, who was a social actor and three ministries that were merged into the Ministry of Immigration, Integration, National Identity and Co-Development. Following the separation of urban and integration policies, which were originally attached to the Ministry of the Urban Policy, ACSE was first placed under the umbrella of the Ministry of Integration and later transferred to the authority of the new Ministry of Immigration, Integration, National Identity and Co-development. This organisational layering of ACSE as a social actor to the new Ministry resulted in new departmental tensions, now between the staff from ACSE, who was responsible for integration matters and ministerial staff. As former regional director or FASILD and ACSE Frédéric Callens explained, the inclusion of integration policy under the new Ministry led to the exclusion of social actors like the ACSE from strategic planning and governance, which was dominated by the ministerial staff (Interview with a former regional director of FASILD and ACSE Frédéric Callens 2016). The tensions arose between the Ministry staff and the ACSE 
staff as the latter were not given freedom to act and their decision-making powers were limited. This organizational layering can equally cause policy deadlocks.

Those who come from ACSE, they find themselves in the new organism that tells them to do things differently, to do different things and to use different methods, other objectives and other actors (Interview with the former head of the Office or territorial, social and cultural integration in the Ministry of the Interior Marie-José Bernardot, 2016).

Sarkozy's attempt to incorporate integration matters under the Ministry of Immigration, Integration, National Identity and Co-Development led to the exclusion of social actors from the decision-making and implementation process, which was dominated by ministerial actors. These departmental conflicts, in addition to departmental competition between Ministry of Integration and Social Affairs, Ministry of the Interior and Ministry of Work, led to the integration policy deadlock and to the eventual dissolution of the Ministry in late 2010.

\section{Conclusion}

Using the case of Sarkozy's integration policy, this paper contributed to the public policy literature by demonstrating how mechanisms that explain policy change also can account for policy deadlock. In this paper I argued that policy deadlock can be explained through institutional change, specifically institutional layering, which triggers departmental competition within newly created or merged structures, resulting in policy deadlock and further institutional change. The paper emphasizes that institutional change does not necessarily cause policy change as previously theorized, but instead can lead to policy deadlock, causing further institutional change, rather than policy change. Furthermore, when departmental tensions occur as a result of layering, the new core does not necessarily suppress the old core, as it has been demonstrated with the 
case of integration policy within ACSE under the authority of the Ministry of Urban Policy.

First integration policy deadlock occurred when integration was placed under the authority of the Ministry of Urban Policy, as a result of the changing policy paradigm from anti-discrimination to equal opportunities. It is explained by institutional layering that fused urban policy with integration policy, triggering in departmental tensions, which resulted in re-separation of these policies and transfer of integration matters to the Ministry of the Interior. Second integration policy deadlock occurred when the Ministry of Immigration, Integration, National Identity and Co-Development that was designed to improve integration was abolished three years later. Institutional layering of three ministers: the Ministry of Integration and Social Affairs, the Ministry of the Interior and the Ministry of Work under one led to the resistance among former ministers and their administrations to work together on integration leading to its dissolution.

Institutional layering and departmental competition Ministry of Immigration, Integration, National Identity and Co-Development can be useful not only in shedding light on why there has not been any progress on a given policy, but they can also be used to understand the changing nature of the institutions that are responsible for it.

\section{Disclosure statement}

No potential conflict of interest was disclosed by the author.

\section{References}

Abadan-Unat, N. 1997. Ethnic Business, Ethnic Communities, and Ethno-politics Among Turks in Europe. In Immigration into Western Societies: Problems and Policies. ed. Uçarer, E., and D. Puchala. London: Pinter. 
Adida, C., D. Laitin, and M. Valfort. 2014. Muslims in France: Identifying a Discriminatory Equilibrium. Journal of Population Economics 27(4): 10391086.

Beach, D., and R.B. Pedersen. 2013 Process-Tracing Methods: Foundations and Guidelines. Ann Arbor: University of Michigan Press.

Beach, D., and R.B. Pedersen. 2016. Selecting Appropriate Cases when Tracing Causal Mechanisms. Sociological Methods and Research 47(4): 1-35.

Beamer, G. 2002. Elite interviews and state politics research. State Politics and Policy Quarterly 2(1): 86-96.

Bengtsson, B., and N. Hertting. 2014. Generalization by mechanism: Thin rationality and ideal-type analysis in case study research. Philosophy of the Social Sciences,44(6): 707-732.

Bennett, A. 2010. Process Tracing and Causal Inference. In Rethinking social inquiry: Diverse tools, shared standards, 2nd edn, ed. H. Brady and D. Collier. New York, NY, United States: Rowman \& Littlefield Publishers.

Bennett, A., and J. Checkel. 2015. Process tracing: From metaphor to analytic tool. Cambridge, United Kingdom: Cambridge University Press.

Bezes P. 2007. The 'steering state' model: the emergence of a new organizational form in the French Public Administration. Sociologie du Travail 49: 67-89.

Bezes P. 2009. Réinventer l'Etat: Les reformes de l'administration française (19622008). Paris: PUF.

Bezes. P. 2016. Challenges to French Public Administration: Mapping the Vitality of Its Knowledge Sources. In The Oxford Handbook of French Poltics. ed R. Elgie, E Grossman, and A. Mazur.

Birnbaum, P. 1982. The Heights of Power: An Essay on the Power Elite in France. University of Chicago Press.

Blatter, J., and T. Blume. 2008. Co-Variation and causal process tracing revisited: Clarifying new directions for causal inference and generalization in case study methodology. Qualitative Methods 6(1): 29-34.

Bourdieu, P. 1996. The State Nobility: Elite Schools in the Field of Power. Oxford: Polity. 
Carvalho, J. 2016. The Effectiveness of French Immigration Policy Under President Nicolas Sarkozy. Parliamentary Affairs 69(1): 53-72.

Carvalho, J. 2017. Mainstream Party Strategies Towards Extreme Right Parties: The French 2007 and 2012 Presidential Elections. Government and Opposition: An International Journal of Comparative Politics 54(2):1-22.

Carvalho, J., A. Geddes. 2012. La politique d'immigration sous Sarkozy: Le retour à l'identité nationale. In Politiques publiques 3: Les politiques publiques sous Sarkozy, ed. J. Maillard. Paris: Presses de Sciences Po.

Cole, M., and J. Fenwick. 2003. UK Local Government: The Impact of Modernization on Departmentalism. International Review of Administrative Science 69(2): 25970 .

Consterdine, E. 2015. From zero migration to the migration state: Whitehall cultures, institutional conversion and policy change. International Journal of Public Policy 11 (4): 129-142.

Consterdine, E. 2018. Labour's Immigration Policy: The Making of Migration State. Palgrave Macmillan.

Drake, H. 2011. Contemporary France. Houndmills, Basingstoke, Hampshire: Palgrave Macmillan.

Duelund, P. 2016. The impact of the new nationalism and identity politics on cultural policy-making in Europe and beyond. In Challenging Identities: European Horizons. 1st edn. ed. P. Madsen. Routledge.

Escafré-Dublet, A. 2014. Mainstreaming Immigrant Integration Policy in France. Brussels: MPI Report.

Falleti, TG., and JF. Lynch. 2008. From process to mechanism: Varieties of Disaggregation. Qualitative Sociology 31(4): 333-339.

Falleti, TG., and JF. Lynch. 2009. Context and causal mechanisms in political analysis. Comparative Political Studies 42(9): 1143-1166.

Freeman, G. 1995. Modes of Immigration Politics in Liberal Democratic States. International Migration Review 19(4): 881-908. 
Freeman, Gary. 2001. Client Politics or Populism? The Politics of Immigration Reform in the United States. In Controlling a New Migration World, ed. V. Guiraudon, and C. Joppke. London: Routledge.

Genieys, W. 2005. The Sociology of Political Elites in France: The End of an Exception? International Political Science Review 26(4): 413-430.

George, A.. and A. Bennet. 2004. Case studies and theory development in the social sciences. Cambridge, MA: MIT Press.

Guiraudon, V. 2005. Immigration politics and policies. In Developments in French

Politics 4, ed. A. Cole, P. le Galès, and J. Levy. New York: Palgrave MacMillan.

Guiraudon, V., and C. Joppke. 2001. Controlling a New Migration World. London: Routledge.

Hampshire, J., and T. Bale. 2015. New Administration, New Immigration Regime: Do Parties Matter After All? A UK Case Study. West European Politics 38(1): 145166.

Hollifield, J. 2014. France. In Controlling Immigration. A Global Perspective, ed. J. Hollifield, P. Martin, and P. Orrenius. Stanford: Stanford University Press.

Ivaldi, G. 2008. Inequality, Identity and the People: New Patterns of Right-Wing Competition and Sarkozy's 'Winning Formula' in the 2007 French Presidential Election. American Political Science Association (APSA) Annual Meeting. Boston. https://halshs.archives-ouvertes.fr/halshs-00320692/document

Joppke, C. 1998. Why Liberal States Accept Unwanted Immigration. World Politics 50(2): 266-293.

Kavanaugh, D., and D. Richards. 2001. Departmentalism and joined up government. Parliamentary Affairs 54(1): 1-18.

King, G., R. Keohane, and S. Verba. 1994. Designing Social Enquiry. Scientific Inference in Qualitative Research. Princeton University Press.

Lemarié, A. 2012. Le candidat Sarkozy réhabilite l'identité nationale. Le Monde, 05 March 2012. https://www.lemonde.fr/election-presidentielle2012/article/2012/03/05/le-candidat-sarkozy-rehabilite-1-identitenationale_1652134_1471069.html 
Le Monde. 2009. Besson relance le débat sur l'identité nationale. Le Monde, 25 October 2009. https://www.lemonde.fr/politique/article/2009/10/25/besson-relance-ledebat-sur-1-identite-nationale_1258628_823448.html

Lepinard, E., and P. Simon. 2008. From integration to antidiscrimination... to diversity? Antidiscrimination policies and politics in French workplace. European Commission.

Lipsky, M. 1980. Street-Level Bureaucracy: Dilemmas of the Individual in Public Services. New York: Russel Sage Foundation.

March J., and Olsen J. 1989. Rediscovering Institutions. New York: Free Press.

March J., and Olsen J. 1995. Democratic Governance. New York: Free Press.

Marlière, P. 2013 'Sarkozysm': From Political Ambivalence to Hard Right. In The Sarkozy Presidency: Breaking the Mould?, ed. G. Raymond. Palgrave.

Marthaler, S. 2008. Nicolas Sarkozy and the politics of French immigration policy. Journal of European Public Policy 15(3): 382-397.

Mayer, N. 2007. Comment Nicolas Sarkozy a rétréci l'électorat Le Pen. Revue française de science politique 57(3): 429-445.

Mucchielli, L., and V. Goaziou. 2007. Quand les banlieus brûlent... Retour sur les émeuts de novembre 2005. https://www.travailsocial.com/telecharger/conference_banlieues.pdf

Noël, O. 2008 Politique de diversité ou politique de diversion? Du paradigm public de lute contre les discriminations à sa déqualification juridique. Revue Asylon(s) 4, Institutionnalisation de la xénophobie en France, http://www.reseauterra.eu/article764.html

Ocak, Ö. 2016. Immigration and French national identity under neoliberalism: Sarkozy's selective immigration politics as a performance of sovereignty. Patterns of Prejudice 50(1): 82-95.

Robinson, O. 2013 Sampling in Interview-Based Qualitative Research: A Theoretical and Practical Guide. Qualitative Research in Psychology 11(1): 25-41.

Sarkozy, N. 2007. Mon projet. Ensemble tout devient possible. iPolitique, http://ipolitique.free.fr/francepolitique/sarkozy2007-2.pdf 
Senat (n. d.) Annexe 2. Le fond d'action et de soutien pour l'intégration et la lutte contre les discriminations. Senat, https://www.senat.fr/rap/a04-033/a040338.html

Sides, J., and J. Citrin. 2007. European opinion about immigration: The role of identities, interests and information. British Journal of Political Science 37(3): $477-504$.

Simon, P. 2007. Comment la lutte contre les discriminations est passé à droite. Mouvements 4(52):153-163.

Simon, P. 2009. La stratégie de la discrimination positive: Sarkozy et le débat français sur l'égalité. Modern and Contemporary France 17(4): 435-450.

Somerville, W. 2007. Immigration Under New Labour, Policy Press, Bristol.

Suleiman, E. 1974. Politics, Power and Bureaucracy in France: The Administrative Elite. Princeton University Press.

Suleiman, E. 1978. Elites in French Society: The Politics of Survival. Princeton University Press.

Tansey, O. 2007. Process tracing and elite interviewing: A case for non-probability sampling. PS: Political Science and Politics 40(4): 765-772.

Robinson, O. 2014. Sampling in Interview-Based Qualitative Research: A Theoretical and Practical Guide. Qualitative Research in Psychology 11(1): 25-41.

Van der Leun, J. 2003. Looking for Loopholes. Processes of Incorporation of Illegal Immigrants in the Netherlands. Amsterdam: Amsterdam University Press.

Wihtol de Wenden, C. 2012. Les questions de citoyennetté, de diversité et de nation en référence au récent débat sur l'identité nationale en France. In La communauté politique en question: Regards croisés sur l'immigration, la citoyenneté, la diversité et le pouvoir, 1st ed., ed. M. Labelle, J. Couture and F. Remiggi. Presses de l'Université de Quebec. 
